\title{
Achieving HBSE Competencies through Service-Learning
}

\author{
Sarah E. Twill \\ Kathy Elpers \\ Kathy Lay
}

\begin{abstract}
Service-learning pedagogy allows social work educators to create meaningful learning opportunities for students and better prepare them for practicum, while at the same time, meeting a community need. This paper outlines the relevance of incorporating service-learning into the social work curriculum, specifically the human behavior and the social environment (HBSE) area. Using Bloom's taxonomy as a guide, the authors propose how the CSWE competencies and practice behaviors specific to HBSE may be assessed using service-learning pedagogy. An example is reviewed to illustrate how service-learning can assist faculty and students achieve the HBSE competencies and practice behaviors. Finally, implications for service-learning as a pedagogical strategy for social work education are discussed.
\end{abstract}

Keywords: Service-learning, human behavior in the social environment curriculum, CSWE competencies

\section{INTRODUCTION}

The concept of service-learning in higher education as well as in social work education is not new and is frequently utilized as an experiential form of teaching to connect students in the community in a variety of formats. Service-learning has a long history in higher education beginning with the Morrill Act establishing land grant institutions and continuing through the passage of the National and Community Service Trust Act (Phillips, 2007; Titlebaum, Williamson, Daprano, Baer, \& Brahler, 2004). Based on early involvement with the community beginning with the establishment of the Hull House, the values of the social work profession, and the Council on Social Work Education (CSWE) practicum requirements, service-learning and social work complement one another in that they serve to assist students achieve competencies.

How service-learning is defined and incorporated as a pedagogical methodology has varied in social work education, depending on the course and the instructor's perspective on service-learning methods (Bringle \& Hatcher, 2002; King, 2003; Larson, 2008; Palm \& Toma, 1997; Teater \& Baldwin, 2009; Todd, 2008; Waters \& Moran, 2001). "Servicelearning (SL) is a collaborative teaching and learning strategy designed to promote personal growth, civic learning, and academic enhancement” (Ash \& Clayton, 2009, p. 11). Jacoby (1996) defined service-learning as "a form of experiential education in which students engage in activities that address human and community needs together with structured opportunities intentionally designed to promote student learning and development. Reflection and reciprocity are key concepts of service-learning” (p. 5).

Sarah E. Twill, Ph.D., MSW, is an Associate Professor in the Department of Social Work at Wright State University; Kathy Elpers, Ed.D., MSW, is an Associate Professor of Social Work at the University of Southern Indiana; and Kathy Lay, Ph.D., is an Associate Professor in the Indiana University School of Social Work, Indianapolis. 
McCrea (2004) reviewed and summarized the commonality of service-learning definitions to include the following components: "the service must meet an actual community need; the learning from service must be clearly integrated with course objectives; reflection about the service experience is essential; and the relationship between service recipients and learners must be reciprocal” (p. 5). These service-learning components are similar to those discussed by Ash and Clayton (2009) which highlighted community partnerships, meaningful activities, and guided critical reflection. Ash and Clayton also postulated that the impact of service-learning will enable students to have a better understanding of their personal and professional learning while better understanding how the world works, as well as their place and responsibility to the world.

Social work has a long-standing tradition of community-based service that dates back to the early settlement houses (Blank, 1998). Service is essential to the mission of the social work profession. The core values designated by the National Association of Social Workers are: “....service, social justice, dignity and worth of the person, importance of human relationships, integrity, [and] competence” (NASW, 1999). Service as an ethical principle demands that social work practitioners put service to others above their own interests and use their professional skills throughout their careers in a volunteer capacity (NASW, 1999).

The model utilized for service-learning in social work courses should include connecting and collaborating with a community partner so that the students and community partner benefit in a meaningful way from the service-learning activity and uphold the values and ethics of the profession. Moreover, students should be guided on how to develop professionally and personally from the service-learning experience through critical reflection on the knowledge, skills, and social work values integrated in bridging theory and practice. Service-learning, from this pedagogical approach, parallels the paradigm shift of postmodernism in social work education. Postmodern approaches emphasize understanding the world of others through their lens, which encompasses culture, history, personal, and social constructs rather than objectifying individuals through theory or cause-and-effect alone. In other words, social workers need to practice with a stance of open-mindedness rather than a deterministic or linear view of knowing what is best or needs to happen (Greene, 2009; Payne, 2005). By incorporating servicelearning within this framework, social work education can provide an integrative approach for students to understand social work from a real world context, connect with the profession, develop social work competencies, and critically reflect on their personal and professional growth.

In summary, social work students, through service-learning, are provided with "active, relevant, and collaborative learning..." (Bringle \& Hatcher, 2000, p. 274.) in a agency or community context. The focus of the engagement benefits the community, while at the same time, the context provides a rich learning environment for the student. Service-learning creates a learning experience in which students and community members engage in collaboration with social work's “...emphasis on social justice and the amelioration of social problems...” (Lemieux \& Allen, 2007, p. 309). 


\section{Service-Learning is not Synonymous with Volunteerism and Practicum}

Service-learning is often used synonymously and intertwined with volunteer work, community service, and field placements (Larson, 2008). Essential to service is volunteerism. Many agencies and community organizations rely on volunteerism and in the current economy volunteerism may mean the continuation of services to those in need. Lundahl and Wicks (2010) document the benefits of volunteerism related to the value of professional skills for agencies and also the importance to individuals and groups who have a life-long commitment to service.

Lowe and Reisch (1998) acknowledged that social work programs, for over a century, have developed educational models linking the classroom to community-based learning. These early service-learning models were influenced by the work of John Dewey and Paul Freire which stemmed from an "apprenticeship model of education" (p. 292). Building on these previous models, schools or departments of social work have adapted and expanded their educational programs to include a repertoire of communitybased learning activities including volunteering, community service, and field placements. However, it is service-learning that most often serves to reinforce a commitment to future civic engagement (Bringle \& Hatcher, 2000).

Although all of these types of community-based activities are often described as service-learning, there is some disagreement among social work educators regarding the differences between volunteering, social work practicums, and service-learning (King, 2003; Lemieux \& Allen, 2007). As part of assignments for social work courses, faculty often require students to perform a number of hours to volunteer or provide community service for a community project or with a social service organization. Practicum requires a certain number of hours a student must work in a social agency to meet the course requirements. Nevertheless, although all of these community-based educational activities involve students and a connection with the community in some form, either on a micro or macro level, not all of these course activities are service-learning.

The principles of service learning including engagement for the public good, reciprocity with the community partner, the public dissemination of knowledge with those outside of the academy, and students' critical reflection of experiences differentiates service-learning from other teaching pedagogies (Heffernan, 2001). Performing community service or volunteering largely focuses on service, field placements primarily focus on student learning while service-learning emphasizes both service and learning. Larson (2008) viewed field placements as developing learning objectives based primarily on the student, faculty, and social work program's goals as opposed to developing common goals and service activities that are mutually beneficial. Although some would argue that both the student and the agency benefit from volunteering and student field placement, these types of activities do not always include components of organized and collaborative partnerships with community agencies, critical reflection, civic engagement, personal growth, as well as integrating social work knowledge, skills, and values with practice. In summary, service-learning is a pedagogical strategy, in the context of a course, which requires intentional planning, partnering with community organizations, and focusing on both service and learning for 
the benefit of the agency and student within the framework of social work values and course outcomes (Ash \& Clayton, 2009; Bringle \& Hatcher, 1995; King, 2003; Lemieux \& Allen, 2007). Additionally, students "reflect on the service activity in such a way as to gain further understanding of course content, a broader appreciation of the discipline, and an enhanced sense of civic responsibility" (Bringle \& Hatcher, 1995, p. 112).

\section{HBSE AND SERVICE-LEARNING}

Students often begin their social work educations with limited practical experience or formal study of human behavior and the social environment (HBSE). Many are from other disciplines that do not incorporate contextual influences or the dynamic interaction between individuals and their environment. Kropf and Tracey (2002), writing specifically about MSW students negotiating the transition from the foundation year to the concentration curriculum, postulated that service-learning can be an "educational bridge" that enable students to understand and apply social work concepts (p. 63). Social work is a discipline that demands the practitioner acknowledge and take into account the social, political, environmental, and historical contexts of human strengths and challenges. This calls for real world examples along with academic content. Service-learning provides experiential learning through civic engagement.

Theory for HBSE facilitates how individuals make meaning of human behavior and their social environments. How individuals make meaning influences how others and the social world are viewed, as well as how human strengths and struggles are defined. Social work practitioners, as life-long learners, must maintain a rigorous and current study of HBSE theory that is relevant to the historical, cultural, political, and global societal influences. Faculty are often challenged to choose a pedagogy that prepares future practitioners for this on-going task of theory application to the real world.

Understanding HBSE theory should not be an abstract endeavor that has no relevance or influence on social work practice; therefore, connections for the learner with the real world are essential. We all theorize by constantly making meaning of everyday life experiences (Flax, 1999). However, all theorizing and theory are not created equal. Personal meaning making and theorizing are subject to bias and judgments that are often absent of critical reflection. Service-learning, along with the presentation of academic content and critical reflection, facilitates an examination of value judgments that shape our thinking. It is essential to make explicit those implicit assumptions that ultimately influence our practices (Flax, 1999).

A mere understanding of human behavior theory through knowledge acquisition does not prepare students for real world practice. Therefore, instructors strive to challenge students to move from a basic understanding of HBSE theory to synthesis and evaluation (Bloom, 1956), as well as think critically about the potential harm of applying abstract theory to individuals and the social environment. In order to facilitate this learning, students must be provided with experiences that allow application of theory in the real world as well as oral and written structured critical reflection on their experiences (Ash \& Clayton, 2004; Lay \& McGuire, 2010). This brings theory alive for the learner as opposed to abstractly studying theory in a classroom that is void of real world 
experiences and the challenges of the social world. Active and relevant learning experiences (Bringle \& Hatcher, 2000) have the potential for deeper learning and require direct contact with the subject matter (Lundahl, 2008). In this case, the subject matter is theory regarding human behavior and the social environment.

Theory is not truth. It is an abstraction that seeks to predict, explain, and make meaning of the social world. Theory is constructed in a historical, social, and political context (Finn \& Jacobson, 2003). Because it is subject to certain contexts in its construction, faculty may become partial to theoretical understandings that are a reflection of popular cultural explanations of HBSE. For example, Erickison's psychoanalytically oriented developmental theory was based solely on the male developmental experience, yet it is generalized as if it is applicable to all (Schriver, 2011).

Life stage theory, like many human behavior theories, provides a metaphor for understanding development; however, it does not tell us the terrain of life experiences. Social problems may influence individual and collective experiences. For example, the experience of homelessness may alter one's developmental process in ways that both strengthen and challenge. By focusing our lens only on the individual living in homelessness, the struggle may be framed as belonging to the person and the struggle viewed as a "...result of personal deficiencies, such as substance abuse..." (Cronley, 2010, p. 319).

In that theories are abstractions with the potential for cultural, historical, and political biases, our pedagogy must include opportunities for students to reflect and examine theory in the real world Service-learning brings real world experiences into the classroom. The application of theory is no longer a mere abstraction. These student experiences challenge linear and reductionist approaches that strip individuals, groups, families, and communities of their social context. Human behavior does not happen in a vacuum where abstractions can simply be applied. Our theories must reflect the complexity of the social environment.

The factors discussed above position human behavior and the social environment as a course that is ideal for service-learning. Theory is abstract and can be difficult for students to appreciate without real world experiences. In order to be relevant, practical application is necessary with the inclusion of critical reflection that seeks to bring into focus the social work mission of social justice and the social change. Service-learning provides settings where the context of people's lived experiences challenge abstractions that may be removed from the realities of practice.

\section{OPERATIONALIZING THE HBSE COMPETENCIES}

In 2008, the Council on Social Work Education (CSWE) redesigned the social work competencies used for program accreditation (Council on Social Work Education, 2010). Human behavior in the social environment (HBSE) content was defined and practice behaviors were established. The following is the core competency for foundation education in HBSE and the practice behaviors which stem from it: 
Educational Policy 2.1.7-Apply knowledge of human behavior and the social environment.

Social workers are knowledgeable about human behavior across the life course; the range of social systems in which people live; and the ways social systems promote or deter people in maintaining or achieving health and well-being. Social workers apply theories and knowledge from the liberal arts to understand biological, social, cultural, psychological, and spiritual development.

Social workers:

- Utilize conceptual frameworks to guide the processes of assessment, intervention, and evaluation; and

- Critique and apply knowledge to understand person and environment. (Council on Social Work Education, 2010).

Along with the other competencies, social work faculty have begun reshaping curriculum and programs to meet the new competencies. Based on the authors' personal experiences at three different universities, conversations with other faculty around the country, and postings on the Association of Baccalaureate Social Work Program Directors (BPD) listserve, we contend that programs have faced challenges in conceptualizing, creating, and assessing the new competencies. For example, at the 2011 Baccalaureate Program Directors Meeting, many sessions were devoted to the new competencies. Faculty reported multiple ways of operationalizing practice behaviors and their assessments. Some programs have developed competencies exams and rubrics, while other programs have approximately four hundred assessments of students' knowledge and behaviors. In this paper, we suggest that service-learning is one pedagogy that will assist social work faculty in addressing the competencies and practice behaviors.

In order to provide a framework for identifying and assessing practice behaviors using service-learning pedagogy, we propose that a framework from Bloom's Taxonomy be utilized. Bloom (1956) articulated six classifications in the cognitive domain that are essential to learning. The classifications are knowledge, comprehension, application, analysis, synthesis, and evaluation. During the development of the taxonomies, Bloom found that the majority of testing students were exposed to required recall of facts, the lowest level of intellectual engagement. Bloom believed that the classifications were sequential and represented a cumulative hierarchy. The higher levels represent more sophisticated and critical thinking. Since its introduction, critiques have been made and revisions proposed; these include considering critical thinking as a continuum rather than hierarchical, that there is some overlap in the categories, and that the taxonomy should be multidimensional (Anderson, et al., 2001; Marzano \& Kendall, 2007). Changes were also made to rename the categories to be verbs (remember, understand, apply, analyze, evaluate, and create) (Anderson, et al., 2001). For the purpose of this paper, we recognize that readers can debate the critiques and modifications to the original taxonomy, but contend that the basic premise that there are differences in the complexities of critical thinking and that these differences aid in planning curriculum, instruction, and assessment make rational sense for examining our topic. 
An example will best illustrate how to connect the CSWE competencies in HBSE to the taxonomy. Examples of learning objectives for practice behavior A (Utilize conceptual frameworks to guide the processes of assessment, intervention, and evaluation) and practice behavior B (Critique and apply knowledge to understand person and environment) are given for each category in the taxonomy (See Table 1, next page).

\section{HBSE SERVICE-LEARNING EXAMPLE}

The following is an example of a service-learning experience that permits students to demonstrate HBSE competencies. This experience focuses on a mentoring program in a public school, but a range of settings including homeless shelters, assisted living facilities for seniors, and child development centers have all been used as service-learning sites by the authors. Engaging in service-learning experiences requires students to use higher level cognitive domains such as applying, analyzing, evaluating, and creating knowledge related to HBSE theory and social work practice. In the next section, the level of Bloom's taxonomy in which the students were thinking and performing will be highlighted in italics or an explicit example will be given.

\section{Overview of the Mentoring Experience}

The college students engaged in the service-learning are juniors in the baccalaureate social work program. The course takes place prior to the senior practicum. The HBSE course includes both micro and macro theories of HBSE and is taught over a ten week quarter. Staff from the Office of Service Learning orients the college students to the philosophy of service-learning and the policies and procedures of the tutoring program.

This service-learning experience takes place at a K-8 school in an urban center. Students in the school struggle with academic proficiencies as measured by standardized testing (Ohio Department of Education, n.d.). The subject proficiencies range from a low of $2.9 \%$ for $8^{\text {th }}$ grade social studies to a high of $55.8 \%$ for $6^{\text {th }}$ grade reading $(75 \%$ pass rate is considered proficient). Over $96 \%$ of the K-8 student body identifies as Black or biracial, $100 \%$ of the students are classified as "economically disadvantaged," and over $20 \%$ of students are identified as having a disability.

The social work students interact with each assigned K-8 student for 30 minutes each week over the course of seven weeks; at the end of seven weeks, social work students have interacted with each student for a minimum of 3.5 hours. The K-8 students may benefit from the tutoring/mentoring because they have an opportunity to have positive adult interactions and receive assistance with academic material. Social work students may benefit from the service-learning because they have the opportunity to apply HBSE course content, practice beginning social work skills like rapport building, and be exposed to challenges faced by a public education system in a local, urban community. 


\section{Table 1. Practice Behaviors and Learning Objectives}

Practice Behavior:
A. $\quad$ Utilize conceptual
frameworks to guide
the processes of
assessment,
intervention, and
evaluation
B. Critique and apply
knowledge to
understand person
and environment
* Examples of theories
are given; however,
students were often given
the choice of selecting a
theory discussed in class
or the textbook. This is
especially true at the
higher levels of the
taxonomy. This was
purposeful to allow
students to begin to
develop their theoretical
orientation.

Learning Objective \#1: Remember (skills: recognize, recall)

A. Students will identify the levels in Maslow's Hierarch of Needs. *

B. Students will list the feminist critique of Freud's psychodynamic theory.

Learning Objective \#2: Understand (skills: explain, classify, summarize)

A. Students will explain the key characteristics of social capital in their own words so that someone not familiar with the concepts could understand them.

B. Students will summarize the postmodern critiques of Kohlberg's stages of moral development.

Learning Objective \#3: Apply (skills: execute, implement)

A. Based on their servicelearning experiences, students will demonstrate how social learning theory applies to the students they are mentoring.

A. Based on their servicelearning experiences, students will articulate how the systems perspective guides their practice.

B. Based on their servicelearning experiences, students will chose which theory best helps guide social work practice with a student who they are mentoring.
Learning Objective \#4: Analyze (skills: analyze, differentiate )

A. Based on their service-learning experiences, students will analyze if the tenets of the Erickson's stages of development are true of today's children and youth.

A. Based on their service-learning experiences, students will analyze if using the family life cycle perspective is appropriate with the service-learning population.

B. Based on their service-learning experiences, students will consider person-in-environment factors influence human development.

Learning Objective \#5: Evaluate (skills: critique)

A. Based on their service-learning experiences, students will critique how the social constructionist perspective either supports or opposes social work values.

B. Based on their service-learning experiences, students will articulate why/how some theories are appropriate to use in guiding practice with one client, but not another.

Learning Objective \#6: Create (skills: plan, produce, generate)

A. Based on their service-learning experiences, students will pick a theory discussed and propose modifications to it to incorporate changes in modern society and social work values.

A. Students will compare and contrast how such changes to the theory may impact assessment, intervention, and evaluation.

B. Students will demonstrate their understanding of a theory by appropriately engaging with the student they are mentoring. 
Social work students are expected to select one of the students they tutor to use as the "client" for their application of HBSE theory. Through the tutoring (e.g. assessing developmental milestones and learning tasks), guided learning activities (e.g., writing a story about family or completing sentences about likes/dislikes), and spontaneous interactions, the social work students learn about the K-8 students and the social environment. This requires students to apply the knowledge they are learning in the classroom to a practice setting. Students are encouraged to listen and make observations of the student, the school personnel, and the larger community in order to evaluate and think critically about the value of HBSE in facilitating meaning making.

In addition to the service-learning in the school, the students organize and participate in a canned food drive that benefits the tutored children. Based on Feeding America's Backpack Program, which recognizes that school children often go hungry on weekends, the college students organize a food drive of kid-friendly foods. Using HBSE theory as a guide to analyze why American children live with hunger and the community's response to the problem, they participate in the food drive to provide the K-8 students with additional food over the Thanksgiving and winter holidays.

\section{Description of the Assignments that Help Achieve the HBSE Competencies}

Students complete a portfolio over the course of the quarter. The portfolio has twelve assignments, which account for over $60 \%$ of the course grade (the remaining points are achieved from reading and lecture quizzes). As part of the portfolio, students select one of the K-8 students with whom they have been working for the focus of their servicelearning experiences. Before they began to apply the theoretical perspectives, students complete a brief review of the literature based on a topic related to urban youth. Students also complete an ecomap which sets the stage for the theoretical analysis. The literature review assignment requires students to understand and summarize current knowledge about at-risk youth, while the ecomap assignment requires students to create a comprehensive pictorial representation of person-in-environment factors that influenced their "client's" life. Students then complete portfolio assignments regarding the application and evaluation of two micro theories (e.g., developmental), one mezzo theory (e.g., family systems theory), and one macro theory (e.g., the social capital approach). In completion of the portfolio, students choose one theory to evaluate using the criteria (e.g., coherence and conceptual clarity, comprehensiveness) set forth by Hutchison (2008, p. 31). This assignment also asks students to create knowledge by suggesting changes to a theory that would be more inclusive of their experiences working with atrisk urban youth. Throughout the aforementioned application of theory assignments, the students are using their work with their K-8 student to inform their social work analysis.

Students complete scholarly reflection assignments at the beginning and end of the service-learning experience and twice during the course of the quarter. The first reflection assignment is a pre-write to establish baseline knowledge about their understanding of the population with whom the student will be serving. The final reflection requires students to grapple with professional issues of social justice and service. The other two reflection assignments allow students to choose from guided reflection topics such as addressing cultural competence, ethical dilemmas faced during the service-learning, and a national 
and global comparison of youth and public education; all of which serve to demonstrate competencies relevant to HBSE. The second reflection assignment requires that students contextualize their comments by applying, analyzing, evaluating, and (sometimes) creating knowledge related to HBSE theory and social work practice.

\section{DISCUSSION}

Social work is primarily a practice profession; social workers are licensed professionals working in all arenas in society, in a variety of roles, at the micro and macro practice levels to ensure that all members of society receive the necessary services to function at their highest capacity. Incorporating service-learning pedagogy as a integral part of the curriculum provides social work educators an opportunity to create meaningful learning opportunities for students and better prepare them for practicum (Kropf \& Tracey, 2002), while simultaneously benefiting the community and increasing their understanding of and commitment to the public good. Service-learning philosophies also align with the values and ethics of the profession, as well as Council of Social Work Education's (CSWE) standards. The CSWE's Educational Policy and Accreditation Standards state the following as the goal of social work:

The purpose of the social work profession is to promote human and community well-being. Guided by a person and environment construct, a global perspective, respect for human diversity, and knowledge based on scientific inquiry, social work's purpose is actualized through its quest for social and economic justice, the prevention of conditions that limit human rights, the elimination of poverty, and the enhancement of the quality of life for all persons (CSWE, 2010).

According to Zastrow (2010) social work is unique from other professions in its mandate and primary focus on providing social services and advocating for the social welfare of others. From our experiences, service-learning in HBSE courses typically occur in agencies serving vulnerable populations. When this is true, in addition to mastering the HBSE content, social work students have the opportunity to practice their values of service, while at the same time, focusing on an issue of social inequality. Further, service-learning complements academic content and the achievement of competencies. Service-learning can facilitate the promotion of social work values, provide opportunities for personal and professional growth, and foster civic responsibility.

As faculty rethink social work education in light of the CSWE 2008 changes in HBSE competencies and practice behaviors (Council on Social Work Education, 2010), designing learning objectives and the assignments that measure them will be important in helping programs demonstrate a competency based education. The shift to addressing the competencies through a demonstrated practice behavior aligns with the methodology of service-learning. Interactions with clients are fluid, dynamic, and unpredictable. Students must learn to determine if a given theory helps explain human behavior and formulate a hypothesis under such conditions. Providing a real life setting in which to practice these skills has pedagogical value. What better evidence of competency is there than when 
students can demonstrate that they understand theory by applying it in a real person-inenvironment setting?

In a well designed HBSE service-learning experience, students will be able to utilize complex critical thinking skills. Bloom's (1956) taxonomy provides a structure for assessing higher level thinking. Using the new HBSE competencies and practice behaviors, students will be able to apply and evaluate the effectiveness of a theory. The nuances of a theory, including identifying situations in which a theory does not apply, may become illuminated when working with a person rather than a textbook example. Students will also gain practice in identifying a shortcoming or needed modifications of a historical theory which often fails to take into account perspectives of women, people of color, individuals with disabilities, or issues faced by non-Western individuals. Table 1 is intended to give readers at framework for designing HSBE service-learning projects that increase critical thinking and allow a way to measure practice behaviors.

Since the ultimate goal of social work education is to prepare social workers for competent professional practice in their work with individuals, families, groups, organizations, communities, and society at large, taking the classroom into the community is an important and necessary component of the social work curriculum. Service-learning opportunities in HBSE courses will allow students to learn firsthand about social work concepts such as person-in environment, problem solving, and an array of theoretical perspectives, which are essential in understand the sociopolitical and environmental conditions that contribute to the social problems faced by the clients and communities.

\section{References}

Anderson, L. W., Krathwohl, D. R., Airasian, P. W., Cruikshank, K. A., Mayer, R. E., Pintrich, P. R., \& Wittrock, M. C. (2001). A taxonomy for learning, teaching, and assessing: A revision of Bloom's taxonomy of educational objectives. New York: Longman.

Ash, S. L., \& Clayton, P. H. (2004). The articulated learning: An approach to reflection and assessment. Innovative Higher Education, 29(2), 137-154.

Ash, S. L., \& Clayton, P. H. (2009). Learning through critical reflection: A tutorial for service learning students. Raleigh, NC: Authors.

Blank, B. (1998). Settlement houses: Old ideas in new form builds communities. The New Social Worker, 5(1). Retrieved from http://www.socialworker.com/settleme.htm

Bloom, B. S. (1956). Taxonomy of educational objectives: The classification of educational goals. Handbook I: Cognitive domain. NY: David McKay Company.

Bringle, R. G., \& Hatcher, J. A. (1995). A service-learning curriculum for faculty. Michigan Journal of Community Service Learning, 2, 112-122.

Bringle, R. G., \& Hatcher, J. A. (2000). Institutionalization of service-learning in higher Education. The Journal of Higher Education, 71(3), 273-290. Retrieved from http://www.jstor.org/stable/2649291 
Bringle, R. G., \& Hatcher, J. A. (2002). Campus-community partnerships: The terms of engagement. Journal of Social Issues, 58(3), 503-516. doi: 10.1111/1540-4560.0027

Cronley, C. (2010). Unraveling the social construction of homelessness. Journal of Human Behavior in the Social Environment, 20(2), 319-333. Retrieved from http://www.informaworld.com/smpp/title $\sim$ content $=\mathrm{t} 792306870 \sim \mathrm{db}=$ all

Council on Social Work Education. (2010). Educational policy and accreditation standards. Retrieved from http://www.cswe.org/File.aspx?id=13780

Feeding America. (n.d.). Backpack program. Retrieved from http://feedingamerica.org/our-network/network-programs/backpack-program.aspx

Finn, J. L., \& Jacobson, M. (2003). Just practice: Steps toward a new social work paradigm. Journal of Social Work Education, 39(1), 57-78. Retrieved from http://web.ebscohost.com.proxy.ulib.iupui.edu

Flax, J. (1999). Women do theory. In M. Pearsall (Ed.), Women and values: Readings in recent feminist philosophy (pp. 9-13). Belmont, CA: Wadsworth.

Greene, R. (Ed). (2009). Human behavior theory \& social work practice. New Brunswick, NJ: Aldine Transaction.

Heffernan, K. (2001). Fundamentals of service-learning course construction. Boston: Campus Compact.

Hutchison, E. D. (2008). Dimensions of human behavior: Person and environment. Thousand Oaks, CA: Sage.

Jacoby, B. (1996). Service-learning in today’s higher education. In B. Jacoby (Ed.), Service- learning in higher education (pp. 3-25). San Francisco, CA: Jossey-Bass.

King, M. (2003). Social work education and service learning. Journal of Baccalaureate Social Work, 8(2), 37-48. Retrieved from http://www.bpdonline.org/JBSW/AM/ContentManagerNet/Default.aspx?Section=JB $\underline{\text { SW\&Template }=/ \text { TaggedPage/TaggedPageDisplay.cfm\&TPLID }=4 \& \text { ContentID }=3365}$

Kropf, N. P., \& Tracey, M. (2002). Service learning as a transition into foundation field. Advances in Social Work, 3(1), 60-71. Retrieved from http://journals.iupui.edu/index.php/advancesinsocialwork/article/view/29/24

Larson, G. (2008). Community service learning: What does it mean for social work education? Canadian Social Work Review, 25(1), 89-96. Retrieved from http://www.caswe-acfts.ca/en/Canadian_Social_Work_Review_32.html

Lay, K., \& McGuire, L. (2010). Universities engaging with the community through service-learning: Structured critical reflection as a tool for learning. In T. Möltgen (Ed.), Wert und Nutzen ehrenamtlichen Engagements: Reader for CaritasSummerschool (pp. 78-96). Köln, Germany: Butzon \& Becker. 
Lemieux, C. M., \& Allen, P. D. (2007). Service learning in social work education: The state of knowledge, pedagogical practicalities, and practice conundrums. Journal of Social Work Education, 43(2), 309-325. Retrieved from http://www.cswe.org/Publications/JSWE.aspx

Lowe, J., \& Reisch, M. (1998). Bringing the community into the classroom: Applying the experiences of social work education to service-learning courses in sociology. Teaching Sociology, 26(4), 292-298. Retrieved from http://www.asanet.org/journals/ts/

Lundahl, B., \& Wicks, L. (2010). The need to give and the need to receive: Volunteerism in homeless shelters. Journal of Human Behavior in the Social Environment, 20(2), 272-288. Retrieved from http://www.informaworld.com/smpp/title $\sim$ content=t792306870 $\mathrm{db}=$ all

Marzano, R. J., \& Kendall, J. S. (2007). The new taxonomy of educational objectives. Thousand Oaks, CA: Corwin Press.

McCrea, J. (2004). Intergenerational service-learning in gerontology. Association for Gerontology in Higher Education. Pittsburgh, PA. University of Pittsburgh.

Ohio Department of Education. (n.d.). 2008-09 school year report card. Retrieved from http://www.ode.state.oh.us/reportcardfiles/2008-2009/BUILD/018119.pdf

National Association of Social Workers (NASW). (1999). Code of ethics of the National Association of Social Workers. Retrieved from http://www.socialworkers.org/pubs/code/code.asp

Palm, R., \& Toma, D. (1997). Community relationships and partnerships. New Directions for Student Services, 79, 57-65. Retrieved from http://onlinelibrary.wiley.com/journal/10.1002/(ISSN)1536-0768

Payne, M. (2005). Modern social work theory. Chicago, IL: Lyceum Books.

Phillips, A. (2007). Service learning and social work education: A natural but tenuous connection. In M. Nadel, V. Majewski, \& M. Sullivan-Cosetti (Eds.), Social work and service learning: Partnerships for social justice (pp. 3-19). Lanham, MD: Rowman \& Littlefield.

Schriver, J. (2011). Human behavior and the social environment: Shifting paradigms in essential knowledge for social work practice ( $5^{\text {th }}$ ed.). Boston: Allyn \& Bacon.

Teater, B., \& Baldwin, M. (2009). Exploring the learning experiences of students involved in community profiling projects. Social Work Education, 28(7), 778-791. doi:10.1080/02615470802478220

Titlebaum, P., Williamson, G., Daprano, C., Baer, J., \& Brahler, J. (2004). Annotated history of service learning. National Service Learning Clearinghouse. Retrieved from http://www.servicelearning.org/filemanager/download/142/SL\%20Comp\%20Timelin e\%203-15-04 rev.pdf 
Todd, S. (2008). Community service learning: Introduction. Canadian Social Work Review, 25(1), 87-88. Retrieved from http://www.casweacfts.ca/en/Canadian Social_Work Review

Waters, S., \& Moran, A. (2004). Working partnership links ‘different worlds'. Adults Learning, 13(4), 17-21.

Zastrow, C. (2010). Introduction to social work and social welfare: Empowering people. Belmont, CA: Brooks/Cole.

\section{Author's note:}

Address correspondence to: Sarah E. Twill, Department of Social Work at Wright State University. Email: sarah.twill@wright.edu 